\title{
Perspectives and processes in revegetation of arid and semiarid rangelands
}

\author{
C.A. CALL AND B.A. ROUNDY
}

\begin{abstract}
Range revegetation research has been dominated by empirical studies that provide some information about what works or does not work under a given set of conditions, but tell us little or nothing about the underlying ecological processes. Research has emphasized the establishment of vigorous exotic grasses on specific sites rather than the establishment of persistent, blologically diverse plant communities. A more mechanistic research approach is needed to better understand factors governing germination, seedling establishment, and plant community development in natural and synthetic systems to guide revegetation toward biological diversity. This paper evaluates selected aspects of the present knowledge of revegetation science on arid and semiarid lands, and attempts to identify areas for future research direction. Speciflc concepts and aspects of succession and plant community development, such as seedbed ecology, temporal and spatial patterns of resource availability and use, species life history traits, and species interactions are important areas of research. Continuous measurement of detailed environmental and biological data at the appropriate scale (down to the size of small seeds) will allow development of mechanistic models which can be used to predict plant establishment and community development for different environmental conditions.
\end{abstract}

Key Words: seedbed ecology, succession, simulation modeling, competition, vegetation structure

Rangeland revegetation emerged as an applied science in the U.S. about 100 years ago, following a noticeable downward trend in range condition associated with the settlement and intensive use of arid and semiarid lands. From the early 1890's to the mid 1930's, revegetation efforts attempted to halt land degradation resulting from past stocking practices with domestic animals and the abandonment of cultivated former rangeland. Early revegetation efforts relied heavily upon conventional agricultural principles and practices, and were largely unsuccessful because seed was only available for cultivated forage plants adapted to more mesic environments and site preparation methods were often inadequate (Stoddart et al. 1975). Since the mid 1930's, development of improved plant materials, equipment, and site preparation and planting methods have allowed great progress in the revegetation and improvement of deteriorated grazing land, cropland, recreational land, and wildlife habitat. Revegetation technology for more drastic disturbances, such as those associated with energy and mineral extraction, developed markedly during the 1960 's and 1970 's with the passage of state and federal legislation affecting land reclamation (DePuit 1986).

Revegetation of arid and semiarid rangelands where annual precipitation is less than $600 \mathrm{~mm}$ is constrained, variably influenced, and complicated by the nature of land disturbances and widely divergent climatic and site conditions (DePuit 1986). The size, intensity, frequency, and regularity of occurrence of disturbances vary considerably, and play a major role in community

\footnotetext{
Authors are assistant professor, Range Science Department, Utah State University, Logan 84322-5230; and associate professor, School of Renewable Natural Resources, University of Arizona, Tucson 85721 . This paper was supported by the Utah Agricultural Experiment Station and the Arizona Agricultural Experiment Station. Approved by the Utah Agricultural Experiment Station as journal paper 4011.

Manuscript accepted 4 May 1991.
}

development and organization (Bazzaz 1983). Climatic factors, primarily low and erratic precipitation and extremes in temperature, exert an overriding effect on the success or failure of a revegetation practice, regardless of the intensity of manipulation treatments used to prepare seedbeds and control undesirable plants (Bleak et al. 1965, Robocker et al. 1965, and Tadmor et al. 1968). Opportunities for establishing a stand by natural or artificial revegetation arise at unpredictable intervals over time. Silcock (1986) estimated that favorable establishment conditions would occur 1 year out of 4 in semiarid regions of Australia. Bleak et al. (1965) suggested that limited precipitation on arid salt desert shrublands in the Great Basin may only allow natural or artificially induced seedling recruitment once or twice every 15 years.

Revegetation has developed more as a technology than as a science over the past several decades. Most research efforts have been site-specific, short-term, empirical studies focused on the immediate problems of plant establishment and soil stability rather than long-term, basic studies focused on the processes of plant establishment and community development (Cairns 1987, DePuit 1989). Extensive testing of different species and site preparation and planting techniques on a variety of sites over many years has emphasized the establishment of exotic perennial grasses in monocultures or simple synthetic communities, but has not provided the guidelines for establishing persistent, biologically diverse plant communities for meeting currently emphasized multiple-use goals. We need a more mechanistic approach in revegetation research to identify and characterize factors influencing the development and persistence of plant communities so that we can determine the potential and the methodologies for establishing biologically diverse communities.

Our purpose in this paper is to provide perspectives on selected aspects of the present state of knowledge of revegetation science in arid and semiarid regions, and identify areas for future research direction. We discuss: (1) the processes of succession because they provide the conceptual basis for planning and evaluating rangeland revegetation projects; (2) vegetation structure because of increasing emphasis being placed on biological diversity and multiple use of rangelands; and (3) seedbed ecology because seed germination and seedling establishment are the most vulnerable stages in the development of natural and synthetic plant communities in arid and semiarid regions. This discussion draws heavily from the emerging science of restoration ecology which focuses on how to reconstruct functional ecosystems on drastically disturbed lands.

\section{Succession/Vegetation Structuring}

Natural revegetation tends to be slow and stochastic on arid and semiarid rangelands, where water frequently limits or prevents plant establishment and growth. In contrast, artificial revegetation approaches attempt to compress the process of plant establishment into a single period, regardless of our inability to predict environmental episodes necessary to drive germination and seedling establishment. As a result, many land managers conceptualize revegetation of disturbed rangelands as an instantaneous phenomenon, where plants are introduced and rapidly establish to form a permanent, static community (DePuit 1986). This perception is 
invalid on many rangelands, where natural or synthetic community development is a long-term, dynamic process that is influenced by factors of disturbance, microsite heterogeneity, climatic fluctuation, and life history attributes of plant species.

The concepts of succession provide the theoretical basis for revegetation. The processes of succession determine the rate and nature of initial revegetation, and continue to influence plant community development long after treatments have been implemented (Redente and DePuit 1988). MacMahon (1987) and Redente and DePuit (1988) have given a modern interpretation to Clementsian (Clements 1916, 1928) processes of succession (i.e., migration, ecesis (establishment), competition, reaction, and stabilization) to try to better understand how succession can be manipulated through reclamation practices on drastically disturbed lands. They concluded that we presently best understand and can most effectively modify the initial processes of succession (i.e., migration and ecesis). Practices like topsoiling, preparing seedbeds, applying fertilizers and amendments, and seeding and transplanting alter the migration of propagules and enhance plant establishment. However, our understanding of the subsequent processes of competition, reaction, and stabilization is seriously lacking. A better understanding of the relationships among plants, animals, microorganisms, soil processes, and climatic factors is needed in order to reestablish stable, functional communities on disturbed rangelands (MacMahon 1987, M.F. Allen 1988, El-Tayeb 1989).

Clements $(1916,1928)$ displayed considerable insight when he developed the previously mentioned processes of succession. However, he oversimplified the overall phenomenon of succession with his concepts of single equilibrium communities and deterministic successional pathways. These concepts were formulated into a successional approach that is still used as the basis for developing and evaluating revegetation. While these concepts may be applicable in subhumid prairie communities studied by Clements and others, they may not be suited to plant communities in arid and semiarid regions where vegetation establishment and change are often responses to exceptional events rather than average conditions (Westoby 1980). Westoby et al. (1989) recently summarized how current ecological (successional) theory allows for alternative stable states, discontinuous and irreversible transitions, nonequilibrium communities, and stochastic effects in succession. They proposed that in many rangeland situations, community dynamics can be more accurately described as a set of discrete states of vegetation and a set of discrete transitions between states, rather than as steady vegetation change along a single continuum. The transitions between the various states are triggered by natural events (weather, fire), by management practices (revegetation, prescribed burning, change in stocking rate), or a combination of the two. Once the states and transitions are known for an area, a land manager could determine under what circumstances revegetation practices would provide a favorable transition or an unfavorable transition.

Discontinuous transitions and alternative stable states have been observed on drastically disturbed rangelands where the major revegetation goal, in many instances, is to manipulate succession toward a replica of a pre-disturbance plant community. E.B. Allen (1988) developed conceptual models for reconstructed sagebrush (Artemisia)-grassland communities in Wyoming to illustrate that different rates and patterns of natural succession could eventually result in a pre-disturbance vegetation, whereas a different trajectory of succession would result in a community with a different species composition. Different trajectories could be caused by chronic edaphic changes, the introduction of persistent alien species, and the absence of essential symbiotic microbes. Many past revegetation efforts on disturbed rangelands have influenced the trajectory of succession. Monocultures of crested wheatgrass
[Agropyron desertorum (Fisch. ex Link) Schult.] in the Great Basin and Lehmann lovegrass (Eragrostis lehmanniana Nees) in the Southwest have remained fairly stable and have resisted the invasion of many native grasses and shrubs for decades (Hull and Klomp 1966, Bock et al. 1986).

Concerns about biological diversity and multiple use have directed attention away from the establishment of monocultures to that of more complex synthetic communities that are representative of natural communities. Although the ecological advantages and resource benefits of mixed communities have been frequently noted (Keller 1979, Brown and Hallman 1984, Vallentine 1989), attempts to establish mixed communities have often been unsuccessful due to differential adaptability, response to herbivory, and competitiveness of the seeded species, which, after all, were chosen for their vigor (Harris and Dobrowolski 1986, Roundy and Call 1988). The highly competitive nature of many herbaceous and woody species has been blamed for the failure of many perennial grass revegetation attempts on arid and semiarid rangelands (Roundy and Call 1988). Much of the effort in manipulation of range vegetation has been directed at the control of competitive woody species to enhance natural or artificial revegetation of perennial herbaceous species. The resultant plant communities may or may not be more diverse than the previous, woodydominated communities, which are themselves often lacking in diversity due to the loss of native herbaceous species. Revegetation science in the future must deal with the feasibility and specifics of establishing compatible species to create diversity.

Although Clements (1916) emphasized the importance of competition in species interactions (as have many range ecologists), other interactions including various mutualisms and predator-prey relations (MacMahon 1987) may facilitate vegetation development (Connell and Slatyer 1977). The effects of shrubs on the environment that benefit establishment and production of associated plants are a good example of these interactions (West 1989). Although shrubs and clusters of shrubs may be allelopathic and/or detrimentally competitive with and reduce productivity of herbaceous vegetation in many cases, they may moderate some stressful environments and increase community productivity in other cases. Shrubs may positively affect water availability. They intercept water from light rains and snow. They may increase infiltration rate and waterholding capacity by improving soil structure through reducing raindrop impact and adding organic matter from litterfall, as well as providing habitat for burrowing animals which create macropores. These processes may even result in more favorable soil morphology for plant growth (such as a greater depth to restrictive horizons) under some shrubs.

Shrubs may also be associated with favorable soil fertility and seedbanks for plant establishment. Shrubs catch wind-blown soil, seeds, and mycorrhizal spores, provide resting sites for animals to bring in nutrients and seeds, and concentrate nutrients through absorption and fixation by roots. Shrub canopies reduce irradiance and reradiation and affect understory temperatures, which may reduce evapotranspiration and increase nutrient cycling. Shrubs may even help reduce insect herbivory of associated plants by providing habitat for spiders and other predators.

These observations, summarized from West (1989), indicate that many important ecological processes are associated with the horizontal and vertical structure of plant communities. These important considerations have often been ignored in revegetation. In some cases, appropriate overstory plantings may increase establishment of understory species, such as do natural nurse plants (Wood and del Moral 1986, Franco and Nobel 1988). The presence of shrubs or trees may also significantly increase the productivity of associated grasses compared to that in shrub-free grass stands (Rumbaugh et al. 1982, Frost and McDougald 1989). An impor- 
tant challenge for revegetation and ecological restoration science is to determine the requirements and positive characteristics of different species, and the planting patterns which maximize ecological productivity and stability (Aber 1987).

It is important that we have the capability to establish complex communities; however, their complexity may obscure our understanding of processes critical in their assembly and development. We could better understand community development, as agriculturalists and foresters do, by assembling and disassembling simplified communities that are similar in critical ways to more complex communities (Jordan et al. 1987). By reproducing the essentials, in terms of growth forms, spatial patterns, and interactions, critical factors such as community structure and function can be understood more clearly. This understanding of the processes that affect a few key species in a simple synthetic community can be extended to the more complex community and possibly to other communities (Gilpin 1987).

Besides the need for a better understanding of the effects of specific plants on their environment and their neighbors, there is also a need for understanding community-wide processes. Research could be directed toward determining the productivity of assemblies of species with known beneficial characteristics, such as nitrogen fixation, mycorrihizal potential, and potential root and canopy structure compatibility.

Range revegetation by Nechaeva (1985) and colleagues in Soviet Central Asia is an example of an attempt to structure ecologically stable mixed shrub-herbaceous communities. The resource goal was to establish communities to fulfill the seasonal dietary requirements for sheep. Shrub species were selected for known environmental tolerances and expected compatibility to more fully utilize soil water and nutrient resources and radiant energy. Competitive ability, phenology, potential allelopathy, habit-forming ability (or the potential modification of the environment) as well as root distribution were considered in species selection. Shrubs were seeded in various species combinations in strips plowed through sedge and grass-dominated rangeland. The plowed strips, or "coulisses", accumulated soil water in the winter which allowed shrubs to germinate. Over time, grasses and sedges filled back in under the shrubs and shrub species density equilibrated. Creation of these "agrophytocenoses" increased forage production by up to 8 times, provided a more nutritional year-round diet for sheep, and maintained greater production during drought than native rangeland. The potential for structuring useful and productive "agrophytocenoses" is probably quite high, but will require considerable research effort and a better basic understanding of the characteristics of numerous species.

\section{Seedbed Ecology}

Plant establishment by seedling recruitment, the dominant type of regeneration for most species in rangeland communities, is only successful when plant requirements for seed germination, seedling establishment, and subsequent growth are matched with the microenvironmental factors of the seedbed (Grubb 1977, Harper 1977). Revegetation literature abounds with studies that describe germination and seedling responses under controlled environmental conditions that are not representative of stochastic environmental conditions found in the field. Conversely, field studies describe germination and seedling responses under natural conditions, but in most cases, critical environmental factors have not been measured in adequate detail to accurately assess how seeds and seedlings are "sensing" and responding to their microenvironment (Mayer 1986). Despite such shortcomings, these studies have improved our knowledge of seedbed environments and their influence on germination and seedling establishment. In fact, comparisons of germination and seedling development characteristics among species in a community offer some clues about how species partition the habitat and develop the structure of a community (Burton et al. 1988, and Evans and Young 1987).

We still try to compensate for our lack of understanding of plant-site relationships by increasing the number of species in seeding mixtures and/or increasing seeding rates (Vallentine 1989). However, seedling recruitment during natural and artificial revegetation is a result of the number of seeds in favorable microsites, or "safe sites", in the seedbed rather than the total number of available seeds (Harper et al. 1965, Young 1988). This number is a function of seed and seedbed characteristics. Seeds of most species germinate best when buried at a proper depth in a firm seedbed. Much of revegetation technology has dealt with the development and application of seedbed preparation and sowing methods to place seeds at the proper depth and in favorable microsites. Although seed burial recommendations have been made for different-sized seeds (Vallentine 1989), few studies have been undertaken to determine where different sowing methods actually place seeds in the seedbed and from which depths or locations seedlings successfully emerge. Using high seeding rates and an intensive sampling procedure (Winkel and Roundy 1991), Winkel et al. (1991a) determined percentages of seeds buried and depth of emergence of seedlings in relation to seedbed treatments. The percentage of seeds buried above the maximum depth of emergence, or biological limit, could then be calculated. The percentage of seeds on the surface, within and below the depth interval of emergence, varied with seed size, seedbed preparation treatment, and rainfall conditions. These kinds of data are needed to better define safe sites and determine the effectiveness of seedbed preparation methods.

Many small-seeded species and certain species with specific physiological requirements (i.e., light for phytochrome transformation, fluctuating temperatures, lack of seed reserves for emergence) must be located on the seedbed surface for germination to occur (Mayer 1986, Young et al. 1987). The role of seed appendages in facilitating seedling establishment of seeds on the soil surface has been recognized (Booth 1987) but has not generally been considered or exploited in revegetation technology. Site conditions (i.e., topography, rockiness, and type and extent of disturbance) and costs can restrict conventional methods of tilling and seeding on many rangelands. A better understanding of surface soil safe site characteristics and functional seed morphology is needed to determine appropriate species, sites, and management to permit less expensive, less capital-intensive seeding methods. These may include broadcast seeding certain seeds with appropriate appendages, size, or morphology on natural seedbeds without soil coverage. Also included might be the use of animals (Simao Neto et al. 1987) or natural drainages (J.R. Barrow, personal communication) for dispersal of seeds and enhancement of seedling establishment.

Favorable water and temperature conditions for germination and establishment on or near the surface are associated with surface soil microtopographical features such as cracks, depressions, rocks/gravel, and plant litter, and proximity to neighboring vegetation (Harper et al. 1965, Harper 1977). Only a few detailed studies (Evans and Young 1987, Fowler 1988, Winkel et al. 1991 b) have determined the types of microsites that are adequate for germination and establishment of a limited number of range species. Surface cracks, depressions, and/or obstructions have been shown to modify temperature and moisture conditions in a variety of environments. In a classic study, Harper et al. (1965) reported increased emergence from seeds of Plantago spp. placed in depressions (1.25-2.50-cm deep) and near ridges (1.25-2.50-cm above the surface) in an artificial seedbed. They also reported increased emergence of Bromus rigidus Roth when seeds were sown on 
seedbeds comprised of small aggregates $(<1.25-\mathrm{cm}$ diameter), and of $B$. madritensis $L$. when seeds were sown on seedbeds comprised of larger aggregates (3-5-cm diameter). Differences in emergence of the Bromus species were related to the types of contact different shaped seeds made with the water-supplying surface of the aggregates. Fowler (1988) observed that rocks (no mention of size) created safe microsites for red threeawn (Aristida longiseta Steud.) and Texas grama (Bouteloua rigidiseta (Steud.) Hitchc.) in a shortgrass community in Texas by providing shade and reducing evaporative losses. In a controlled environment study, Winkel et al. (1991b) determined the effects of several natural microsites, typical of semidesert grasslands in the southwestern U.S., on seedling emergence of 3 warm-season perennial grasses in relation to soil water conditions. Under all soil water conditions, emergence of sideoats grama (Bouteloua curtipendula (Michx.) Torr.), blue panic (Panicum antidotale Retz.), and Cochise lovegrass (Eragrostis lehmanniana Nees $\times E$. tricophera (Nutt.) Wood) from surfacesown seed was highest from gravel $(2-5-\mathrm{mm}$ diameter, $10-\mathrm{mm}$ deep), followed by cracks (2-5-mm wide, $15-20-\mathrm{mm}$ deep, and $80-100-\mathrm{mm}$ long), and least from the bare soil surface. Soil water potential remained above $-1.5 \mathrm{MPa}$ several days longer in the gravel microsites than on the bare surface sites as water became more limiting, indicating that seedlings in gravel sites may not be subject to desiccation before the next rainfall event.

Seedbed ecology studies in sagebrush-grassland communities in the Great Basin region demonstrated that more seedlings of Wyoming big sagebrush (Artemisia tridentata Nutt. spp. wyomingensis Beetle and Young), Thurber needlegrass (Stipa thurberiana Piper), downy brome (Bromus tectorum L.), and medusahead [Taeniatherum asperum (Sim.) Nevski] emerged from cracks and pits than on the bare soil surface (Eckert et al. 1986, Evans and Young 1987). Microenvironmental monitoring indicated that depressed sites retained moisture at the surface longer and had more favorable atmospheric and temperature regimes than the smooth soil surface. Depressions also created more favorable conditions for soil coverage of seeds (i.e., trapping wind-blown particles, sloughing of sides of depressions). Development of the deepfurrow rangeland drill and the rangeland imprinter was based, in part, on this safe-site concept, and this equipment has enhanced seeding success on some arid and semiarid soils (Asher and Eckert 1973, Haferkamp et al. 1987).

The type and amount of litter on the soil surface can have variable effects on seedbed microenvironments and seedling recruitment. In southwestern U.S. semidesert grasslands, Winkel et al. (1991b) found emergence of 3 warm-season perennial grasses was greater when surface sown seed was covered with litter (excelsior cut into $20-50-\mathrm{mm}$ lengths, $10-20-\mathrm{mm}$ deep) than not; however, emergence was lower than from a gravel-covered soil surface. Evans and Young (1987) reported much greater emergence of downy brome, medusahead, and Russian thistle (Salsola iberica Sennen \& Paul) from seeds under litter than from seeds on the soil surface in an annual rangeland community in Nevada. Litter greatly modified diurnal and seasonal patterns of air temperature and diurnal range of relative humidity at the soil surface, and delayed soil water depletion in the soil surface layer. The atrazinefallow method for control of downy brome and subsequent establishment of perennial grasses was based on the concept of reducing litter accumulations on the soil surface to decrease downy brome seedling establishment (Eckert and Evans 1967).

In contrast to the species-litter responses above, Evans and Young (1987) noted that tumble mustard (Sisymbrium altissimum L.) had greater germination and seedling establishment on a bare soil surface than under litter. The seedcoat of this species produces a mucilage upon wetting that gradually dries, conserving moisture and providing more continuous contact between the seed and the soil particles in the seedbed. In a shortgrass community in Texas, Fowler (1988) observed that establishment of red threeawn and Texas grama was greater on microsites free or almost free of litter. In this more mesic environment, even small amounts of litter may habor pathogens that reduce germination and seedling survival when soil moisture and soil surface relative humidity increase following rainfall.

The type and depth of litter has also been noted to influence the establishment of shrub and grass seedlings in sagebrush-grassland and salt desert shrub communities in the Great Basin. The accumulation of leaves of basin big sagebrush (Artemisia tridentata Nutt. spp. tridentata) under shrub canopies may prevent seeds from reaching the soil surface whereas herbaceous litter creates a porous media that allows seeds to contact the soil surface (Young 1988). Soil mounds beneath shrubs have a higher organic matter content and are more granular in structure than soils in nearby vegetationfree interspaces that form vesicular crusts which restrict water infiltration and seedling emergence. Eckert et al. (1978) studied the influence of soil morphological characteristics of these surfaces and found that perennial grass establishment following shrub removal and drill seeding was much greater on shrub mounds, where litter had mineralized, than in interspaces.

The proximity and developmental stage of neighboring plants can also influence the suitability of a seedbed microsite. In the shrub mound-bare interspace pattern in the Great Basin, the establishment of shrub and herbaceous species is further complicated by competitive interactions with established shrubs. The most favorable site for establishment based on soil surface conditions is near the margin of the shrub canopy, but most developing seedlings cannot effectively compete for soil water in such close proximity with established shrubs (Young 1988). In most instances, seedlings establish in cracks in the shrub interspaces until shrubs naturally senesce or are eliminated by a disturbance. In contrast to the observations of Young (1988), Owens and Norton (1989) reported greater survival for basin big sagebrush sheltered by mature sagebrush than for unsheltered seedlings in central Utah. They suggested that higher survival may have been partially due to protection from desiccation. In the Patagonian arid steppe of Argentina, seedling survival of Bromus setifolius Presl. was much greater in bare interspace microsites than in microsites adjacent to shrubs (Mulinum spinosum (Cav.) Pers.) encircled by a ring of bunchgrasses (Soriano and Sala 1986). There was no difference in germination between the 2 microsites; but, as soil water became more limiting during the summer period, soil in bare interspaces dried out at a slower rate. Soriano and Sala (1986) suggested that to accelerate community recovery, there must be an increase in the number of seeds at optimum microsites or an increase in the density of these microsites.

In a patchy shortgrass community in Texas, Fowler (1988) noted that safe microsites for the establishment of red threeawn and Texas grama were not necessarily characterized by a reduced density of surrounding plants. Both species survived better and grew larger the first year if they were located within $2 \mathrm{~cm}$ of seedlings or juvenile plants of either species. Effects of improved soil water and atmospheric temperature conditions apparently outweighed the effects of competition between seedlings and juvenile plants in this dry environment. A direct positive effect of neighbors on seedlings (i.e., facilitation) was unlikely; rather, the presence or a surviving neighbor was an indication that the microsite had been favorable for the neighboring plant in the past, and could still be favorable for further recruitment. However, Fowler (1988) also observed that the safeness of microsites within a quadrat $(45 \times 90 \mathrm{~cm})$ varied from year to year and even month to month, thus preventing these 2 grass species from ever developing stable spatial age and size distributions within a site. 
To better understand recruitment and subsequent growth in naturally and artificially revegetated communities, one can use niche quantification and site-matching techniques to select plant species that would improve long-term community stability (Burton et al. 1988). Variability in soil moisture and other attributes can be described by a frequency distribution of soil measurements made over time or over space in experimental growth studies or by direct gradient analysis in the field (Fig. 1). The frequency distribution

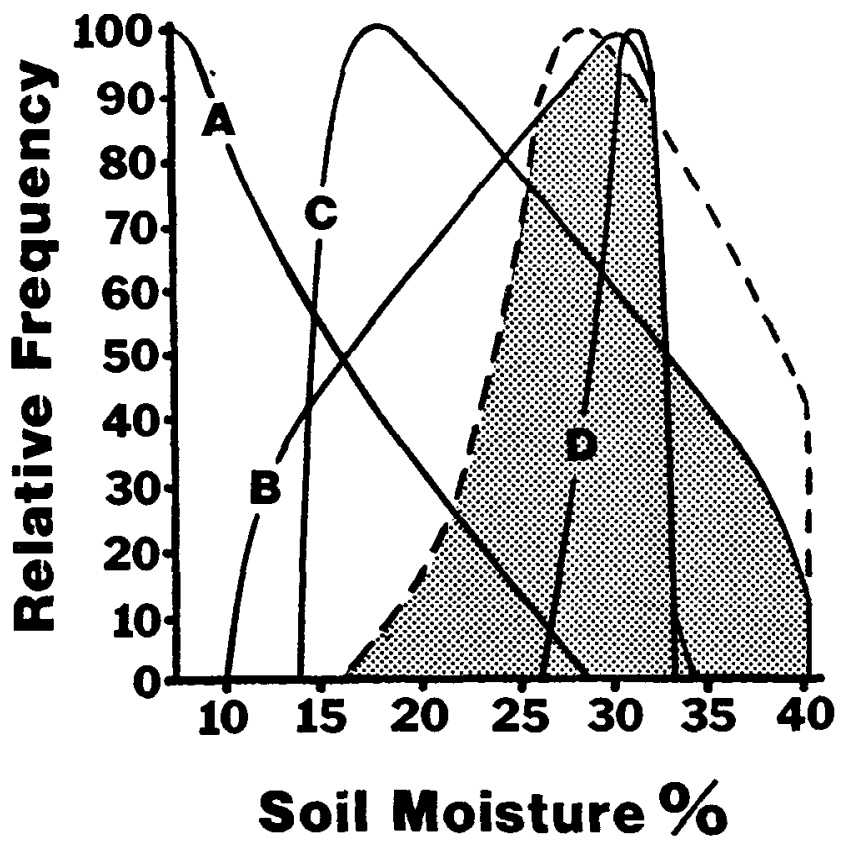

Fig. 1. Overlay of standardized moisture response curves for 4 species (lines A through D) and a moisture-defined environmental space (dashed line) for a hypothetical range site. The shaded area represents the maximum occupancy ( $83 \%$ in this example) of the environmental space possible for this set of species. Note the overlap between species, particularly species $B$ and $D$, along the soil moisture gradient. Adapted from Burton et al. 1988.

can be smoothed to form a curve and the area under the curve is defined as the available environmental space for that resource. Environmental space approximates the range and frequency of conditions to which the plants will be exposed. Gradient response curves, describing the realized niche of each species can then be overlaid on the environmental space curve (Fig. 1). Niche overlap can be estimated, and the best mixture of species can be selected to match the site, filling the environmental space as fully as possible to prevent invasion by undesirable species.

\section{Predicting Germination/Seedling Responses}

We need to better recognize that revegetation processes in rangeland communities, particularly in arid and semiarid regions, are regulated by episodic rather than average environmental conditions. Successful establishment of a species may require the cooccurrence of a seed source, seed placement in favorable microsites, precipitation adequate to stimulate germination, recurrent precipitation for seedling establishment, and possibly low herbivory and/or absence of competition during establishment (Noble 1986). According to the state-and-transition model of Westoby et al. (1989), emphasis could be placed on estimating the probabilities of climatic conditions relevant to revegetation processes and implementing revegetation practices where and when conducive climatic conditions are likely.

To really understand the processes and effectiveness of different methods used to enhance seedling establishment, we need to mea- sure the seed microenvironment and corresponding biological responses (germination, root growth) associated with these methods. We need to measure natural as well as modified seedbeds to determine the importance of factors such as litter, gravel, microtopography and salts (for natural osmoconditioning-Roundy 1987) in creating suitable temperature and moisture pretreatments and establishment conditions for different precipitation scenarios. Unfortunately, it is not practical to characterize seed environments for a wide variety of range sites and microsites. An alternative approach involves the modeling of appropriate water and temperature conditions for germination and seedling development in seedbeds based on climatic data. This would allow one to predict the effects of weather and revegetation treatments on seedbed conditions, and indicate what biological responses are important to establishment under different conditions.

Several models have been developed to estimate soil temperature and water for agricultural and rangeland soils, but these models have not been adequately tested for simulation of soil temperature and water in the surface layer of the seedbed (Wight and Hanson 1987). The major problem in developing and testing models for simulating soil water and temperature dynamics in the surface layer is the lack of appropriate, continuously monitored field data.

Spatial and temporal variability in soil temperature in the surface layer is easily measured by thermistors or thermocouples but the measurement of surface soil water content and/ or water potential at the microscale of most seeds and seedlings is more difficult because of sampling techniques and sensor characteristics (Harper et al. 1965). Winkel et al. (1991b) determined the gravimetric soil water content from the top $5 \mathrm{~mm}$ of mineral soil from gravel, litter, and bare microsites and still had difficulty differentiating why Cochise lovegrass seedlings had greater emergence from gravel than litter. Although soil water content under litter was similar to or higher than under gravel, they speculated that soil water and relative humidity in the immediate vicinity of seeds may have been greater under gravel than litter. Unfortunately, they could not measure these parameters at the appropriate scale of the small lovegrass seeds. In the previously described surface microtographysoil water study of Evans and Young (1972), the researchers were forced to make pits 3 by $6 \mathrm{~cm}$ and 3,6, or 9-cm deep (larger than naturally occurring depressions) because of the size of gypsum resistance blocks used to measure soil matric potential. In addition, gypsum blocks are only sensitive from -0.5 to $-1.5 \mathrm{MPa}$, preventing the measurement of the full range of diurnal and seasonal moisture conditions in the surface layer in dry environments (Kramer 1983). Fiberglass-resistance-type soil cells are slightly smaller in size and measure a wider range of soil matric potentials (near-saturation to near-air dry) than gypsum blocks (Reynolds et al. 1987), and thus may be more appropriate in the surface layer. However, the fiberglass soil cells still do not measure soil matric potential at the microscale required to sense the immediate environment of a seed. Psychrometers measure total soil water potential for a very small fraction of the soil volume, but they are sensitive to temperature gradients, and thus give inaccurate readings near the soil surface (Brown and Bartos 1982). The neutron scattering technique samples a sphere of soil with a radius of $10-30$ $\mathrm{cm}$ making it difficult to accurately measure soil water content in the surface layer (Rundel and Jarrell 1989). A relatively new technique, time-domain reflectrometry (TDR), shows promise for measuring soil water content in rangeland soils; however, as with neutron scattering, TDR samples a large volume of soil, making it less sensitive to microscale variations in the seedbed (Rundel and Jarell 1989). Thus, the development of sensors that can accurately measure surface soil moisture content at a fine scale on a continuous basis is needed to provide more meaningful soil moisture data 
for seedbed models.

As we refine our measurement and modeling techniques, we can better predict the effects of weather and revegetation treatments on seedbed conditions, and indicate what biological responses are important to establishment under different conditions. The development of accurate models would also permit the linking of laboratory-measured germination and seedling responses to different field conditions (Wight and Hanson 1987).

\section{Conclusions}

Over the past several decades, revegetation technology has progressed more rapidly than revegetation science. Extensive empirical species trials on different sites have provided techniques and guidelines mainly for successfully establishing a few vigorous exotic grasses. To establish more diverse plant communities we need to better understand the successional processes associated with plant establishment and community development. To do so will require the detailed study of the biological requirements and resource use of different species in relation to environmental conditions. By measuring and modeling the physical environment in relation to biological responses we should be able to better determine the quantitative effects of different factors on the successful establishment and persistence of more functional synthetic plant communities.

\section{Literature Cited}

Aber, J.D. 1987. Restored forests and the identification of critical factors in species-site interactions, p. 241-250. In: W.R. Jordan M.E. Gilpin and J.D. Aber (eds), Restoration ecology. Cambridge University Press, N.Y.

Allen, E.B. 1988. Some trajectories of succession in Wyoming sagebrush grassland: Implications for restoration, p. 89-112. In: E.B. Allen (ed.), The reconstruction of disturbed arid lands: An ecological approach. Westview Press, Boulder, Colo.

Allen, M.F. 1988. Belowground structure: A key to reconstructing a productive arid ecosystem, p. 113-135. In: E. B. Allen (ed.), The reconstruction of disturbed arid lands: An ecological approach. Westview Press, Boulder, Colo.

Asher, J.E., R.E. Eckert. 1973. Development, testing, and evaluation of the deep furrow drill arm assembly for the rangeland drill. J. Range Manage. 26:377-379.

Bazzaz, F.A. 1983. Characteristics of populations in relation to disturbance in natural and man-modified ecosystems, p. 259-275. In: H.A. Mooney and M. Godron (eds.), Disturbance and ecosystems. Springer-Verlag, N.Y.

Bleak, A.T., N.C. Frischknecht, A.P. Plummer, and R.E. Eckert. 1965. Problems in artificial and natural revegetation of the arid shadscale vegetation zone of Utah and Nevada. J. Range Manage. 18:49-65.

Bock, C.E., J.H. Bock, K. Jepson, and J.C. Ortega. 1986. Ecological effects of planting African lovegrasses in Arizona. National Geographic Res. 2:456-463.

Booth, D.T. 1987. Diaspores of rangeland plants: ecology and management, p. 202-211. In: G.W. Frasier and R.A. Evans (eds.), Proc. Symp. Seed and seedbed ecology of rangeland plants. USDA-ARS, Washington, D.C.

Brown, R.W., and D.L. Bartos. 1982. A calibration model for screen-caged Peltier thermocouple psychrometers. Res. Pap. INT-293. USDA Forest Serv., Intermountain Forest and Range Exp. Sta., Ogden, Utah.

Brown, D., and R.G. Hallman. 1984. Reclaiming disturbed lands. USDAForest Serv. Equip. Dev. Center, Missoula, Mont.

Burton, P.J., K.R. Robertson, L.R. Iverson, and P.G. Risser. 1988. Use of resource partitioning and disturbance regimes in the design and management of restored prairies, p. 46-88. In: E.B. Allen (ed.), The reconstruction of disturbed arid lands: An ecological approach. Westview Press, Boulder, Colo.

Cairns, J. 1987. Disturbed ecosystems as opportunities for research in restoration ecology, p. 307-320. In: W.R. Jordan, M.E. Gilpin, and J.D. Aber (eds.), Restoration ecology: A synthetic approach to ecological research. Cambridge University Press, N.Y.

Clements, F.E. 1916. Plant succession: an analysis of the development of vegetation. Carnegie Institution Pub. 242. Washington, D.C.
Clements, F.E. 1928. Plant succession and indicators. Hafner Publ. Co., NY.

Connell, J.H., and R.O. Slatyer. 1977. Mechanisms of succession in natural communities and their role in community stability and organization. Amer. Natur. 111:1119-1144.

DePuit, E.J. 1986. Western revegetation in perspective: past progess, present status and future needs, p. 6-34. In: M.A. Schuster and R.H. Zuck (eds.), Proc. High Altitude Revegetation Workshop No. 7. CWRRI Information Ser. 58, Colorado State Univ., Fort. Collins.

DePuit, E.J. 1989. The role of academia in meeting future land reclamation challenges. Paper, Nat. Conv. Soc. of Amer. Foresters, Spokane, Wash.

Eckert, R.E., and R.A. Evans. 1967. A chemical fallow technique for control of downy brome and establishment of perennial grasses on rangeland. J. Range Manage. 20:35-41.

Eckert, R.E., M.K. Wood, W.H. Blackburn, F.F. Peterson, J.L. Stevens, and M.S. Meurisse. 1978. Effect of surface-soil morphology on improvement and management of some arid and semiarid rangelands, p. 299-302. In: D.N. Hyder (ed.), Proc. First Internat. Rangeland Congr. Soc. Range Manage., Denver, Colo.

Eckert, R.E., F.F. Peterson, and J.T. Belton. 1986. Relation between ecological range condition and proportion of soil surface types. J. Range Manage. 39:414-420.

El-Tayeb, O.M. (ed.). 1989. Organic matter and soil microbiology in arid land rehabilitation. Arid Soil Res. and Rehab. 3(2).

Evans, R.A., and J.A. Young. 1972. Microsite requirements for establishment of annual rangeland weeds. Weed Sci. 20:350-356.

Evans, R.A., and J.A. Young. 1987. Seedbed microenvironment, seedling recruitment, and plant establishment on rangelands. p. 212-220. In: G.W. Frasier and R.A. Evans (eds.), Proc. Symp. Seed and Seedbed Ecology of Rangeland Plants. USDA-ARS, Washington, D.C.

Fowler, N.L. 1988. What is a safe site?: Neighbor, litter, germination date, and patch effects. Ecology 69:947-961.

Franco, A.C., and P.S. Nobel. 1988. Interactions between seedlings of Agave deserti and the nurse plant Hilaria rigida. Ecology 69:1731-1740.

Frost, W.E., and N.K. McDougald. 1989. Tree canopy effects on herbaceous production of annual rangeland during drought. J. Range Manage. 42:281-283.

Gilpin, M.E. 1987. Experimental community assembly: Competition, community structure and the order of species introductions, p. 151-161. In: W.R. Jordan, M.E. Gilpin, and J.D. Aber (eds.), Restoration ecology: A synthetic approach to ecological research. Cambridge Univ. Press, N.Y.

Grubb, P.J. 1977. The maintenance of species-richness in plant communities: The importance of the regeneration niche. Biol. Rev. 52:107-145.

Haferkamp, M.R., D.C. Ganskopp, R.F. Miller, and F.A. Sneva. 1987. Drilling versus imprinting for establishing crested wheatgrass in the sagebrush-bunchgrass steppe. J. Range Manage. 40:524-529.

Harper, J.L. 1977. Population biology of plants. Academic Press, London.

Harper, J.L., J.T. Williams, and G.R. Sagar. 1965. The behavior of seeds in soil. I. The heterogeneity of soil surfaces and its role in determining the establishment of plants from seed. J. Ecology 53:273-286.

Harris, G.A., and J.P. Dobrowolski. 1986. Population dynamics of seeded species on northeast Washington semiarid sites, 1948-1983. J. Range Manage. 34:46-51.

Hull, A.C., and G.J. Klomp. 1966. Longevity of crested wheatgrass in the sagebrush-grass type of southern Idaho. J. Range Manage. 19:5-11.

Jordan, W.R., M.E. Gilpin, and J.D. Aber. 1987. Restoration ecology: Ecological restoration as a technique for basic research, p. 3-21. In: W.R. Jordan, M.E. Gilpin, and J.D. Aber (eds.), Restoration ecology: A synthetic approach to ecological research. Cambridge Univ. Press, N.Y.

Keller, W. 1979. Species and methods for seeding in the sagebrush ecosystem, p. 129-163. In: The sagebrush eeosystem: A symposium. College of Natural Resources, Utah State Univ., Logan.

Kramer, P.J. 1983. Water relations of plants. Academic Press, N.Y.

MacMahon, J.A. 1987. Disturbed lands and ecological theory: an essay about a mutualistic association, p. 221-237. In: W.R. Jordan, M.E. Gilpin, and J.D. Aber (eds.), Restoration ecology: A synthetic approach to ecological research. Cambridge Univ. Press, N.Y.

Mayer, A.M. 1986. How do seeds sense their environment? Some biochemical aspects of the sensing of water potential, light and temperature. Israel J. Bot. 35:3-16.

Nechaeva, N. (ed.) 1985. Improvement of desert ranges in Soviet Central Asia. Hardwood Academic Publ., N.Y.

Noble, I.R. 1986. The dynamics of range ecosystems, p. 3-5. In: P.J. Ross, P.W. Lynch, and O.B. Williams (eds.), Rangelands: A resource under siege. Australian Acad. Sci., Canberra, Australia. 
Owens, M.K., and B.E. Norton. 1989. The impact of 'available area' on Artemisia tridentata seedling dynamics. Vegetatio 82:155-162.

Redente, E.F., and E.J. DePuit. 1988. Reclamation of drastically disturbed lands, p. 559-589. In: P.T. Tueller (ed.). Vegetation science applications for rangeland analysis and management. Kluwer Academic Publ., Dordrecht, The Netherlands.

Reynolds, T.D., R.B. Shephard, J.W. Laundre, and C.L. Winter. 1987. Calibrating resistance-type soil moisture units in a high-clay-content soil. Soil Sci. 144:237-241.

Robocker, W.C., D.H. Gates, and H.D. Kerr. 1965. Effects of herbicides, burning, and seeding date in reseeding arid range. J. Range Manage. 18:114-118.

Roundy, B.A. 1987. Seedbed salinity and the establishment of range plants, p. 68-81. In: G.W. Frasier and R.A. Evans (eds.), Proc. Symp. Seed and Seedbed Ecology of Rangeland Plants. USDA-ARS, Washington, D.C.

Roundy, B.A., and C.A. Call. 1988. Revegetation of arid and semiarid rangelands, p. 607-635. In: P.T. Tueller (ed.), Vegetation science application for rangeland analysis and management. Kluwer Academic Publ., Dordrecht, The Netherlands.

Rumbaugh, M.D., D.A. Johnson, and G.A. Van Epps. 1982. Forage yield and quality in a Great Basin shrub, grass, and legume pasture experiment. J. Range Manage. 35:604-609.

Rundel, P.W., and W.M. Jarrell. 1989. Water in the environment, p. 29-56. In: R.W. Pearcy, J. Ehleringer, H.A. Mooney, and P.W. Rundel (eds.), Plant physiological ecology. Chapman and Hall, N.Y.

Silcock, R.G. 1986. Strategies for plant introduction and reseeding of semiarid pastoral lands, p. 268-274. In: P.J. Ross, P.W. Lynch, and O.B. Williams (eds.), Rangelands: A resource under siege. Australian Acad. Sci., Canberra, Australia.

Simao Neto, M., R.M. Jones, and D. Ratcliff. 1987. Recovery of pasture seed ingested by ruminants. 1 . Seed of six tropical pasture species fed to cattle, sheep, and goats. Aust. J. Exp. Agr. 27:239-246.

Soriano, A., and O.E. Sala. 1986. Emergence and survival of Bromus setifolius seedlings in different microsites of a Patagonian arid steppe. Israel J. Bot. 35:91-100.

Stoddart, L.A., A.D. Smith, and T.W. Box. 1975. Range management. 3rd Ed. McGraw-Hill, NY.
Tadmor, N.H., M. Evanari, and J. Katznelson. 1968. Seeding annuals and perennials in natural desert range. J. Range Manage. 21:330-331.

Vallentine, J.F. 1989. Range development and improvements. 3rd Ed. Academic Press, N.Y.

West, N.E. 1989. Spatial pattern-functional interactions in shrub-dominated plant communities, p. 283-305. In: C.M. McKell (ed.), The biology and utilization of shrubs. Academic Press, N.Y.

Westoby, M. 1980. Elements of a theory of vegetation dynamics in arid rangelands. Israel J. Bot. 28:169-194.

Westoby, M., B. Walker, and I. Noy-Meir. 1989. Opportunistic management for rangelands not at equilibrium. J. Range Manage. 42:266-274.

Wight, J.R., and C.L. Hanson. 1987. The simulation of soil temperature and water regimes associated with seedling establishment on rangeland soils, p. 93-96. In: G.W. Frasier and R.A. Evans (eds.), Proc. Symp. Seed and Seedbed Ecology of Rangeland Plants. USDA-ARS, Washington, D.C.

Winkel, V.K. and B.A. Roundy. 1991. A technique to determine seed location in relation to seedbed preparation treatments. J. Range Manage. 44:91-92.

Winkel, V.K., B.A. Roundy, and D.K. Blough. 1991a. Effects of seedbed preparation and cattle trampling on burial of grass seeds. J. Range Manage. 44:171-175.

Winkel, V.K., B.A. Roundy, and J.R. Cox. 1991b. Influence of seedbed microsite characteristics on grass seedling emergence. J. Range Manage. 44:210-214.

Wood, D.M., and R. del Moral. 1986. Mechanisms of early primary succession in subalpine habitats on Mount St. Helens. Ecology 68:780-790.

Young, J.A. 1988. Seedbeds as selective factors in the species composition of rangeland communities, p. 171-188. In: P.T. Tueller (ed.), Vegetation science and applications for rangeland analysis and management. Kluwer Academic Publ., Dordrecht, The Netherlands.

Young, J.A., R.A. Evans, and G.J. Cluff. 1987. Seeding on or near the surface of seedbeds in semiarid environments, p. 57-61. In: G.W. Frasier and R.A. Evans (eds.), Proc. Symp. Seed and Seedbed Ecology of Rangeland Plants. USDA-ARS, Washington, D.C. 